\title{
Mazindol の棰液と胃酸の分泌機構に対する影響について
}

\author{
白 石 武 昌
東海大学医学部第一生理学教室*
(昭和58年11月 4 日〔特〕)
}

\begin{abstract}
要約：イヌを用いて， mazindol の唾液分泌汇対する作用を検討した．化学刺激と電気刺激による唾液分 泌量を mazindol $2 \mathrm{mg} / \mathrm{kg}$ の静注で減少させ, 自発性唾液分泌を抑制した。唾液分泌压も低下した．睡 液分泌速度に対する作用は, mazindol 投与群と生食投与の対象群の間有意な差はなかった， mazindol 投与群の睡液中と血清中の $\mathrm{Na}^{+}, \mathrm{Cl}^{-}, \mathrm{K}^{+}$に対する作用は両者とも大きな差はなかった。これにより， 先の mazindol の投与により得られた軼液分泌量と分泌の駆動力（分泌圧）に対する抑制効果は，輸送 されるイオン輸送によるものでなく，他の作用機序の介在が示唆された．ラットを用いて， mazindol の 末梢性と中枢性の胃酸分泌汇対する作用を検討した，末梢性の胃酸分泌では，その酸分泌量，分泌の持続 時間ともに影響を与えなかった。 2-DG や insulin によって起こされた中枢性胃酸分泌に対しては，明 らかな抑制作用を示した。 視床下部外側野内に微量投与した場合にも，2-DG による分泌を抑制した。 mazindol は視床下部に直接作用し，そこが統御する胃酸分泌汶して抑制効果を示したことになる. 視 床下部外側野内のブドウ糖感受性細胞に対して, mazindol は特異的に抑制作用を示した。一方，視床下 部腹内側核内のブドゥ糖受容性細胞に対しては明らかな促進作用を示した．以上の成績から，唾液分泌に 対する抑制には視床下部の掑食中枢自身に対する作用が示唆され，胃酸分泌に対しても，分泌を直接統御 するニューロンに対して作用を及ぼすことが推定され，本剤 mazindol の肥満に対する治療効果が期待 される.
\end{abstract}

\section{緒}

\section{言}

近年,「肥満」に対する種々の方面からの関心が高ま っている. それは，肥満が糖尿病や心血管系疾患などの 原因の一つであるばかりでなく，非肥満者に比較して短 命であるとの報告1などがあるからと思われる，その肥 満の代表的成因の一つが過食である，したがって，未だ 不明な点が多々ある「摂食」の機構の解明が重要な意味 をもつ. 著者らは, 従来より研究の一環として, 摂食と 密接な関係にある視床下部によって統御される「中枢性 胃酸分泌」機序の解明を行っている．即ち，視床下部外 側野 (lateral hypothalamic area, LHA) には, 細胞 内外のプドウ糖濃度の低下によって発火し，それにより 胃酸分泌を惹起させるニューロン（gastric type の glucose sensitive neuron）が存在することを確認した. この細胞の LHA 内の分布とその興奮の特性を検討し たところ,これらのニューロンは LHA 内の限定した 部位に存在し, それらは化学刺激と電気刺激の両方に応 答し，その興奮は胃酸分泌に直接関与するだけでなく， これらの細胞群の分布密度の高い部位の micro-lesion

* - 959-11 神奈川県伊勢原町望星台
で著明な hypophagia を生ずることなどから，同時に 摂食行動に対し，重要な役割を果たしている22。 また， その興奮の伝播径路が延喵道の迷走神経背側核の固有の二 ューロンに中継され，迷走神経を伝導して胃の塩酸分泌 細胞（旁細胞）に至ることを確認した32.

本研究はこれらの研究の一環として, 欧米に沶いては 広く肥満の治療に用いられている amphetamine とは, まったく化学構造的に異なる三環化合物であり, 欧米で はすでに市販され，我が国でもその効果が期待されてい る肥満治療剤 mazindol (5-hydroxy-5-p-chlorphenyl, 2-3 dihydro-5-H-imidazol $[2,1-\alpha])$ の種々の研究の 中から, 今回は「胃酸」と「唾液」の分泌機構に対して 興味ある知見を得たので報告する。

\section{実験材料ならびに寒験方法}

唾液分泌関するすべての実験は, 雑種成犬, 体重 $10 \sim 20 \mathrm{~kg}$ (平均 $15.6 \mathrm{~kg}$ ), 6 頭を用いた。実験は, thiopental-Na（Ravonal，田辺） $30 \mathrm{mg} / \mathrm{kg}$ (i.v.) 麻 酔下の急性実験で行った，麻酔は点滴により適時追加し た.

䪽下腺の排出管と鼓索神経の摘出は, Miller の成書4) と生理学実習書5)を参考にした。手術台にイヌを仰位に 


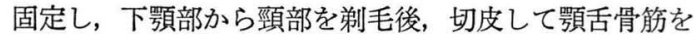
剥離し, マナセパッツ開創器で下顎骨と靧舌骨筋中央部 の間を拡げ, 靧下腺排出後, 舌神経および鼓索神経を周 囲の結合組織から剝離露出した. 顎下腺排出管の一部を 切開して, 直径 $1.75 \mathrm{~mm} 5$ 号のポリエチレン管をそう 入し, 約 $5 \mathrm{~cm}$ 注ど靧下腺の近旁まで入れ結紫し, 以後 の唾液の採取に用いた．鼓索神経は舌神経を中枢部で結 紮し鼓索神経を残し，末梢端拉よび中枢端を切断して， 後述の「電気刺激」により唾液分泌が生じることを確認 した.

唾液分泌刺激は, 化学刺激と電気刺激で行った. 化学 刺激は典型的コリン様物質である carpronium $\left(\mathrm{C}_{8} \mathrm{H}_{13}\right.$ $\left.\mathrm{ClNO}_{2}\right)-\mathrm{HCl}$ (第一) $1 \sim 10 \mu \mathrm{g} / \mathrm{kg}$ を用いた. 投与は すべて, 予め確保しておいた後肢の一側の伏在静脈， あ るいは脛骨静脈内に投与した。電気刺激はすべて鼓索神 経に電気刺激装置（日本光電， SEN-1101，アインレー ターSS-101J) より, パルスの持続時間 2 3 msec, 刺 激強度 $0.1 \sim 10 \mathrm{~V}$, 刺激周波数 $10 \sim 20 \mathrm{~Hz}$ の頻回刺激 10 秒 10 数分間行い，唾液分泌速度，分泌量および分泌圧 などの測定を行った，自発性分泌拈よび刺激により流出 した厜液は, 経時的に目盛りつき試験管に採取し, 後述 のイオン濃度などの測定にも用いた.

唾液の駆動力（分泌圧）は， $3.5 \mathrm{~m}$ の垂直に立てた支 柱に, 内容積と長さを校正しておいた直径 $20 \mathrm{~mm}$ のポ リエチレン管を固定し，前述のイヌの䫇下腺排出管に装 着してめるポリエチレン管に接続して, 持続的鼓索神経 刺激による唾液の「高さ」を読みとった。

唾液分泌速度 $(\mu 1 / \mathrm{min} \cdot \mathrm{g})$ は，前述の鼓索神経の電 気刺激により, 経時的に得られた唾液分泌量と実験終了 後に摘出した顎下腺の重量から計測した.

$\mathrm{Na}^{+}, \mathrm{K}^{+}, \mathrm{Cl}^{-}$の各イオン濃度は, 経時的に採集した 唾液サンプルと比較のため同じく経時的に対側（化学刺 激投与, mazindol 投与側の反対側）より採血した血液 を $3000 \mathrm{rpm} ， 15$ 分間遠心分離した血清サンプルを同時 に測定した.

$\mathrm{Na}^{+}$と $\mathrm{K}^{+}$の定量は, FWQA 法規格の日立 308 型 原子吸光光度計による资光光度法で行った. $\mathrm{Na}^{+}$には $330 \mathrm{~nm}, \mathrm{~K}^{+}$には $767 \mathrm{~nm}$ の波長を用い, 炎は空気一アセ チレンであった. $\mathrm{Na}^{+}$または $\mathrm{K}^{+} 1000 \mu \mathrm{g} / \mathrm{ml}$ の標準液 (和光純薬) で検量線を作成した. $\mathrm{Na}^{+}$は 0 200 $\mu \mathrm{g} / \mathrm{ml}$, $\mathrm{K}^{+}$は $0 \sim 3 \mu \mathrm{g} / \mathrm{ml}$ まで直線が得られた, 測定は, 唾液 の場合 $2000 \mu \mathrm{l}$ と $400 \mu \mathrm{l}$ をそれぞれメスフラスュに入 れ，イオン交換水で $10 \mathrm{ml}$ とした，血清は $100 \mu \mathrm{l}$ と $200 \mu 1$ をとった， $\mathrm{K}^{+}$の場合も唾液 $10 \mu \mathrm{l}$ と $20 \mu \mathrm{l}$, 血清
$50 \mu 1$ と $100 \mu \mathrm{l}$ で, $\mathrm{Na}^{+}$の場合と同様の操作で測定し た.

$\mathrm{Cl}^{-}$の場合は, Cotlove の電量滴定法6)によった. メ ーターは chloride counter (GL-3, 平沼) を用い, 硝 酸 $27 \%$ の平沼クロライドカウンター用電解液（関東化 学)を用いて測定した.

すべての唾液分泌実験終了後, Nembutal の過量投与 により動物を死に至らしめたのち，実験に用いた顎下腺 を摘出し, その重量を計量して前述の分泌速度を算出し た。

胃酸分泌減する実験は，すべてWistar 系雄性ラッ 卜（体重 $280 \sim 350 \mathrm{~g}$ ) を約 50 匹用いた急性実験であっ た。

動物はすべて脳固定装置（SN-2, 成茂) 飞固定し，実 験中, 保温器で直腸温を $37 \pm 1^{\circ} \mathrm{C}$ に保った.

麻酔は, urethane $(500 \mathrm{mg} / \mathrm{kg})$ と chloralose (30 $\mathrm{mg} / \mathrm{kg}$ ）の混合液を大腿部に筇注した. 静注の場合, 薬 物を予めカニュレイションしておいた頸静脈内に 0.1 $0.2 \mathrm{ml}$ 投与した. 皮下注の場合は, $0.5 \sim 0.8 \mathrm{ml}$ を頸背 部に投与した。

胃酸分泌は連続的測定法で, Ghosh and Schild ${ }^{7)} の$ 方法をやや修飾して ${ }^{8}$ 行った。胃潅流液の $\mathrm{pH}$ は 7.1 に

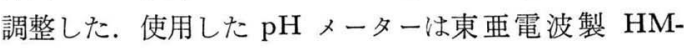
18ET（時に HM-5B を用いた）で，電極は three-inone 型 (TOA, GCT-157) とマイクロエレクトロード 社製の flexible glass microelectrode (MI-520) を用 いた，胃酸分泌のみを観察する時は，東亜の EPR 10A そ prebox PB-128A で記録した.

視床下部の特定部位への微量投与は, 先に著者らが報 告した方法9を用いた. 投与部位は, 後述の LHA の ニューロン活動の記録部位と同じであった．投与量は常 に $1 \mu 1$ であった.

LHA のニューロン活動の記録部位は bregma から 後方 $3.0 \mathrm{~mm}$, 側方 $2.0 \mathrm{~mm}$, 深さは頭頂骨から $8.0 \sim 8.5$ $\mathrm{mm}$ のところで行った，この部位は，「緒言」で述べた 2-deoxy-D-glucose (2-DG), または insulin による化 学刺激や電気刺激によって胃酸分泌を起こさせる LHA ニューロンすなわち gastric type の glucose sensitive neuron の分布密度の最も高い場所であった ${ }^{2,10)}$.

ニューロン活動の細胞外記録は, $3 \mathrm{M}-\mathrm{KCl}$ (D C 抵 抗 $10 \sim 100 \mathrm{M} \Omega$ ) 飞記録部位の確認のため methylene blue を混合した液を充埧し, 後述の多連電極の尖端か ら 20 30 $\mu \mathrm{m}$ 離して両者を瞬間接着剤で結合したガラ ス微小電極を使用した．多連電極は尖端の直径約 $1 \mu \mathrm{m}$ 
の三，五または七連電極（それぞれの抵抗は 50 100 $\mathrm{M} \Omega$ ）加定電流供給装置 ${ }^{11}$ により $20 \sim 100 \mathrm{nA}$ の電流 にて, 電気微小泳動または浸透的投与法で種々の薬物を 細胞外没与した.

ニューロン活動は, 陰極線オンロスコープ（日本光電 VC-9) で観察し，時にそれを連続撮影装置 (PC-2B) に も記録した，午の放電頻度をパルスメーターで分析し， それを ECG のモニター等とともにポリグラフ（RM6200）に，前述の胃酸分泌之同時記録した. ニューロン 活動の記録は, LHA のみならず LHA と機能的に 相反する視床下部腹内側核 (ventromedial nucleus, $\mathrm{VMH})$ 内の ニューロン, 特にグルコース受容性細胞 (glucoreceptor neuron) などに対する影響も観察し た.

実験終了後, $0.9 \%$ 生理的食塩水と $10 \%$ ホルマリンで 潅流固定の後, 脳を摘出, 凍結し $40 \sim 60 \mu \mathrm{m}$ の切片と して, ゼラチン $5 \mathrm{~g}$, 水 $500 \mathrm{ml}, 80 \%$ エタノール $500 \mathrm{ml}$ の溶液を $60^{\circ} \mathrm{G}$ バス内で包埋し，一部は Rucker-Koithane ${ }^{12)}$ の方法で染色, 細織学的検索を行い, 記録部位 または微量投与部位の確認を 3 種のラット脳図譜 ${ }^{13 \sim 15}$ を参照に行った。

本実験に使用した mazindol は図1亿示した化学構 造を有している. 本剤は水に難溶なため, N/10 HCl で $\mathrm{pH}$ を6.0まで下げ，その後，超音波発生装置内 $\left(35^{\circ} \mathrm{C}\right)$ で完全溶解して使用した．本実験に用いた各種薬物の使 用濃度は, mazindol は唾液分泌実験で $140 \mathrm{mM}$, 胃酸 分泌実験では $351.2 \mathrm{mM}$, carpronium はそれぞれ 0.255 $\mathrm{mM}$ と $2.55 \mathrm{mM}$, insulin $40 \mathrm{U} / \mathrm{ml}$ (デンマーク Novo

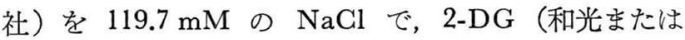
Sigma) とブドウ糖（関東化学）はそれぞれ $153.8 \mathrm{mM}$ の $\mathrm{NaCl}$ で $2 \mathrm{M}$ にしたものを使用した.

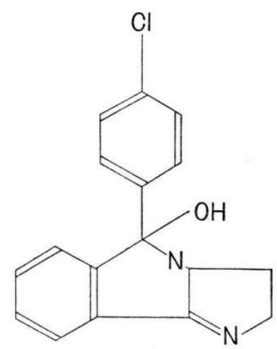

Fig. 1 Chemical structure of mazindol. Although pharmacologically similar to the phenylisopropylamines, it is chemically different.

\section{実 験 結 果}

\section{1. mazindo1 の唾液分泌に対する影響}

イヌの唾液分泌に対する作用はすべて thiopental 麻 酔下において行われ, 唾液分泌量, 分泌駆動力（分泌 圧), 分泌速度, そして各種イオン濃度に対する影響を 検討した.

分泌量に対する mazindol の影響は, すべて化学刺 激として用いた典型的コリン作働性剂である carpronium 単独投与により，一定時間内に得られた唾液量 （それぞれ10，15，20，25 ml） を対照として，その対照 に対しての mazindol の作用の検討の場合，あるいは 電気刺激によって一定時間内に得られた分泌量に対して の mazindol の作用を検討した. 図 2 は, それらの実 験の一部で, carpronium $5 \mu \mathrm{g} / \mathrm{kg}$ (i.v.) によって10分 以内に $15 \mathrm{ml}$ が得られた場合の成績である. carpronium 単独に比して, mazindol $2 \mathrm{mg} / \mathrm{kg}$ (i.v.) の前処置

$15 \mathrm{ml}:$

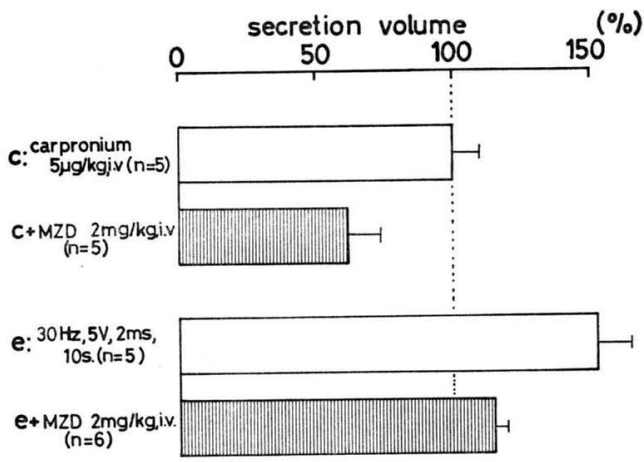

Fig. 2 Effects of mazindol (MZD) on salivary secretion volume in thiopental anesthetized dogs. Mazindol decreased the stimulatory effects of both chemical (carpronium, a typical cholinergic agent, $5 \mu \mathrm{g} / \mathrm{kg}$, i.v.) and electrical (chorda tympanic nerve, $30 \mathrm{~Hz}, 5 \mathrm{~V}, 2 \mathrm{msec}, 10 \mathrm{sec}$ ) stimulation. The upper two bars show mazindol depression of chemically stimulated secretion volume $(15 \mathrm{ml})$. Open bar: control by carpronium ( $5 \mu \mathrm{g} / \mathrm{kg}$, i.v.), $\mathrm{n}=5$. Shaded bar: same after pre-treatment $(15 \mathrm{~min})$ with mazindol (MZD), $2 \mathrm{mg} / \mathrm{kg}$ (i.v.). The lower two bars show mazindol depression of electrically stimulated secretion. Open bar: electrical stimulation only. Shaded bar: electrical stimulation after pre-treatment with mazindol. Mazindol significantly $(\mathrm{P}<0.01$, Student's $t$-test) suppressed both carpronium and electrical stimulation induced salivary secretion. 
（10分前）後の carpronium は61. 2士12.0\%と明らかに $(\mathrm{P}<0.01)$ mazindol は約 $40 \%$ 程化学刺激の carpronium によって賦活された一定時間内の唾液分泌量を抑 制した. また，電気刺激 $(30 \mathrm{~Hz}, 5 \mathrm{~V}, 2 \mathrm{msec}, 10$ 秒)の 場合は $151.8 \pm 11.3 \%$ と, 化学刺激よりも分泌量が多か った. その電気刺激に対する mazindol の作用（刺激

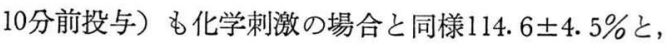

お打むね $25 \%$ もその作用を減弱させた.なお，図の $=100 \%$ は, carpronium 単独投与の対照群に颃いて, 任意に設定した一定時間（この場合 10 分間）に $15 \mathrm{ml}$ に達した 5 例中の 1 例をとり，10分以内に得られた合計

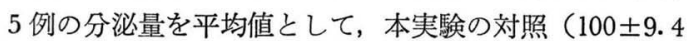
\%)としたものであった. 合計分泌量がそれぞれ 10 , 20，25 ml の場合にも，ほぼ同様の mazindol の唾液分

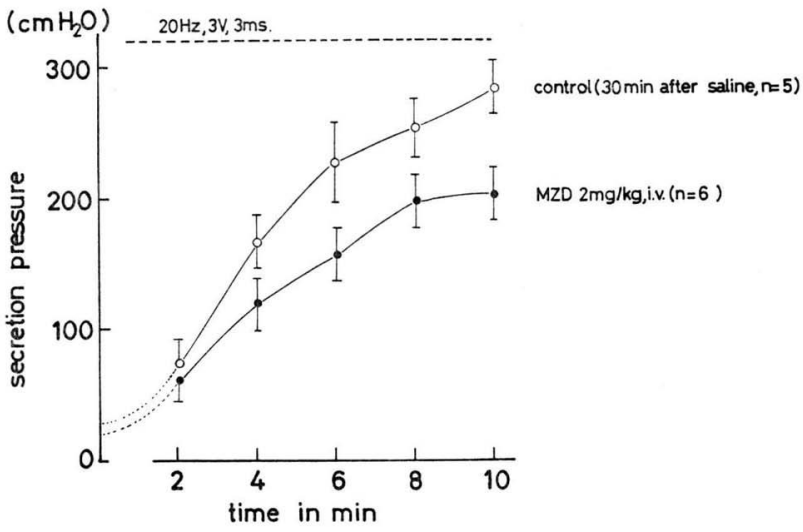

Fig. 3 Effects of mazindol (MZD) on salivary secretion pressure induced by electrical stimulation. Pressure measured in vertical column. Open circles: saline injected control. Closed circles: mazindol injection. Dashed line: time of electrical stimulation. Abscissa: time in min after mazindol injection. Ordinate: secretion pressure in $\mathrm{cm} \mathrm{H}_{2} \mathrm{O}$. Mazindol significantly $(\mathrm{P}<0.01)$ decreased secretion pressure after $4 \mathrm{~min}$.

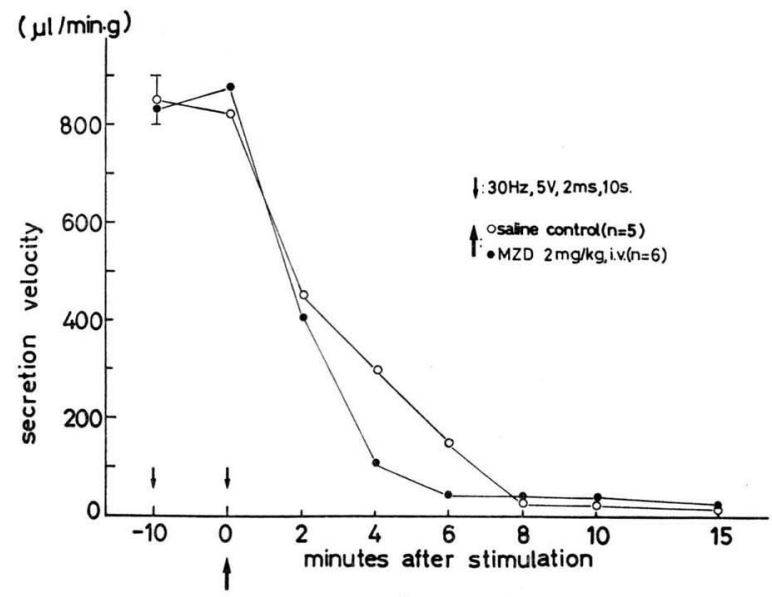

Fig. 4 Effects of mazindol (MZD) on salivary secretion velocity induced by short electrical stimulation. Open circles: velocity of secretion for saline controls. Closed circles: velocity for mazindol treated subjects. Down pointing arrows: electrical stimulation $(30 \mathrm{~Hz}, 5 \mathrm{~V}, 2 \mathrm{msec}$ pulse, $10 \mathrm{sec}$ duration). Left stimulus $(-10 \mathrm{~min})$ : control. Right stimulus: $(0 \mathrm{~min})$ at time of injection. Up pointing arrow: time of injection of saline (control) or mazindol. Abscissa: time before and after injection, min. Ordinate: secretion velocity, $\mu \mathrm{l} \mathrm{min} \mathrm{m}^{-1} \mathrm{~g}^{-1}$. Mazindol did not significantly decrease secretion velocity, except at 4 and $6 \min (\mathrm{P}<0.05)$. 
泌抑制作用が得られた。 また, 定量的実験ではないが, mazindol は乞の後いわゆる「自発的」唾液分泌をも減 少させる傾向があることを否定できなかった.

唾液分泌の駆動力, 即ち分泌圧に対する mazindol の作用を生理的食塩水投与の対照群と比較検討し，その 成績を図 3 に示した. 図は, 10分間にわたる鼓索神経の 電気刺激 $(20 \mathrm{~Hz}, 3 \mathrm{~V}, 3 \mathrm{msec})$ によって惹起された唾液 分泌圧 $\left(\mathrm{cmH}_{2} \mathrm{O}\right)$ を示している. 神経の電気刺激 30 分 前に投与した生食群 $(\mathrm{n}=5)$ は, 刺激により排出（分 泌）する分泌圧の速度は初期に早く，後期にやや遅くは なるが，5 分後には $200 \mathrm{~cm}$ にも達し, 刺激中止の10分 後には $300 \mathrm{~cm}$ にも及んだ. 一方, mazindol $2 \mathrm{mg} / \mathrm{kg}$ 前処置 (刺激 30 分前) の場合には，刺激後 3 分で早く も（約 $15 \mathrm{~cm}$ ）生食投与の対照群と比して低下が認めら れ, その後の上昇曲線の勾配す遥が少さく，6 分で約 $70 \mathrm{~cm}$ と有意差 $(\mathrm{P}<0.01)$ があった。 その傾向は刺激 中から刺激終了まで持続した. 最終值では, mazindol によって約 $80 \mathrm{~cm}(\mathrm{P}<0.01)$ 程重液分泌駆動力（分泌 圧）が有意に低下した．この分泌圧の発生原因は単なる 顎下腺周囲にある筋上皮細胞の収縮のみによるもので なく，唾液の水輸送に直接起因するものであるから， mazindol は水輸送の駆動力そのものを有意に減少させ たことになる。

唾液分泌速度に対する mazindol の影響を, 先に分 泌量に対する作用を検討した標本，すなわち鼓索神経刺 激により，それぞれ種々の刺激強度によって流出した唾 液を用いた．各種の強度に対応する唾液分泌の速度は, 生食投与の対照群と mazindol 投与群との間に大差は 認められなかった．実験終了後摘出した買下腺の重量か ら算出した分泌速度 $(\mu 1 / \mathrm{min} \cdot \mathrm{g})$ についても, 生食, mazindol 投与前に打惊る各々 $60,45,30,20,10$ 分前 の刺激 $(30 \mathrm{~Hz}, 5 \mathrm{~V}, 2 \mathrm{msec}, 10$ 秒) 代対する影響を指摘 することはできなかった。図4 亿, その成績の一部を 示した. mazindol $2 \mathrm{mg} / \mathrm{kg}$ (i.v.) 抢よび対照の生食投 与前10分に抒いては両群之もに差がなく $(830.4 \pm 30.2$, $845.7 \pm 54.8$ ), 以後投与後 15 分間にわたって, 4 分之 6 分 を除き，大きな差は認められなかった．しかし，4 分に 於ける $292.5 \pm 11.0$ と $107.5 \pm 8.8(\mathrm{P}<0.01)$ ，ならび に 6 分に於ける $150.8 \pm 6.4$ と 59.8 $44.2(\mathrm{P}<0.05)$ には 有意の差が認められた，いずれにせよ 8 分後には，両者 の間に差はないことなどから，mazindol の唾液分泌速 度に与光る影響はほとんどないとい党よう。因みに，実 験終了後計測した顎下腺の重量はかなり高頻度に刺激を 繰り返し行ったにもかかわらず，刺激ごとの腺回復時間

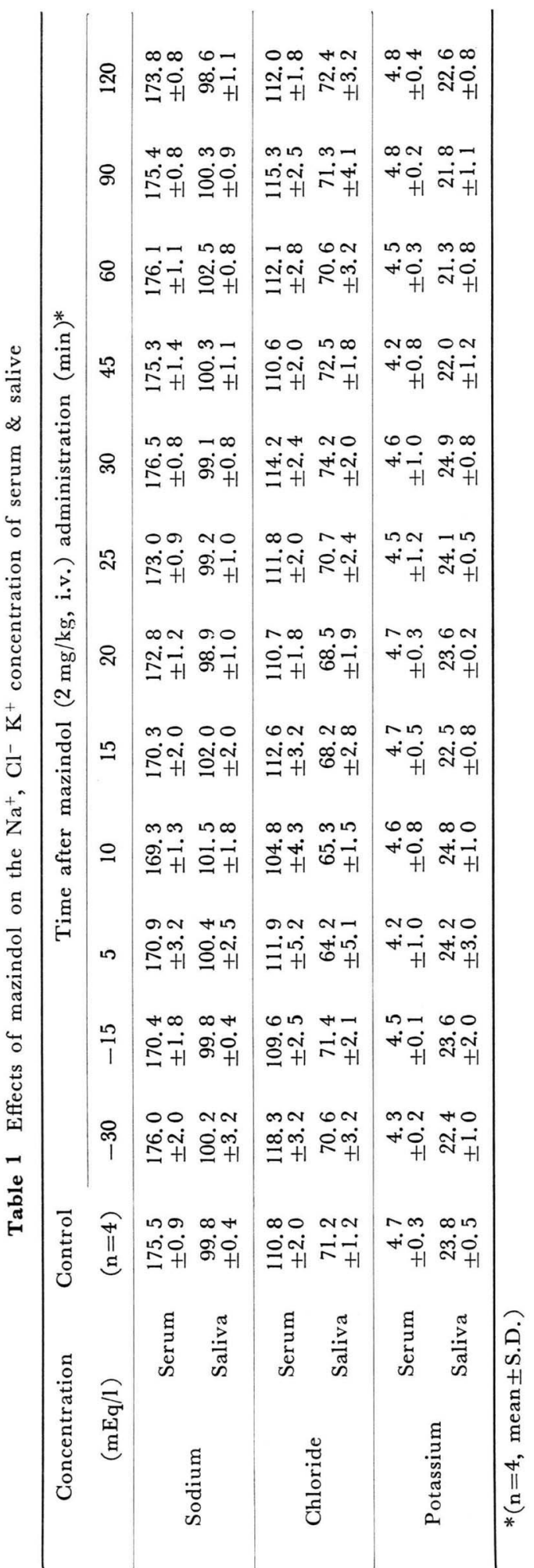


を十分にとったためと思われるが，実験に用いた対側の 実験に用いなかった腺の平均の $16.8 \pm 0.8 \mathrm{~g}(\mathrm{n}=6)$ と 比し, 実験厄用いた腺の重量が $14.2 \pm 2.8 \mathrm{~g}(\mathrm{n}=6)$ と 意外に重かったのが注目された。

唾液腺の場合, 輸送されるイオンの大部分は $\mathrm{Na}^{+}$, $\mathrm{Cl}^{-}$そして K${ }^{+}$である. そこで, mazindol 投与の棰液 中の $\mathrm{Na}^{+}, \mathrm{Cl}^{-}$および $\mathrm{K}^{+}$に対する影響を血清中のそ れぞれのイオンと比較検討してみた. 無処置 4 例のそれ ぞれのイオンの実験開始前, 2 時間（15分間隔 4 回）の 平均値と, mazindol $2 \mathrm{mg} / \mathrm{kg}$ (i.v.) 投与前, 30 分, 15 分と投与後 5 分から 120 分までの血清と唾液の各イオ ン濃度の平均值 $(n=4)$ を表 1 亿総括し，そのうちの 1 例飞ついて因 5 に示した.

唾液分泌対するイオンの依存性の最も高い $\mathrm{Na}^{+}$ そついては, 血清拈よび唾液中の $\mathrm{Na}^{+}$濃度について mazindol 投与の前後で特記すべき大きな差は認められ
なかった. したがって，前述の mazindol 投与による 唾液分泌量, 分泌圧に及ぼす抑制効果は, 輸送される $\mathrm{Na}^{+}$によるものではない別の作用機序の介在を示唆し ている.

$\mathrm{Cl}^{-}$そついても, 血清, 唾液ともに mazindol の 作用は特に認められなかった。たた，唾液の場合, mazindol 投与30分後まで, 無処置の対照に比して平均 值でわずか数 $\mathrm{mEq} / \mathrm{l}$ 程度であるが, 低い值を示した. $\mathrm{Cl}^{-}$濃度の減少は, 唾液分泌機構に直接作用すること なく, また先に mazindol が $\mathrm{Na}^{+}$濃度には影響を及ぼ さないことからも， $\mathrm{Cl}^{-}$濃度に対する作用も含めて， mazindol は唾液のイオンには大きな変化を与えないこ とを示唆するものであった.

$\mathrm{K}^{+}$についての mazindol の影響は，血清拈よび唾 液ともに大きな変化を指摘することはできなかった。 こ のことは, 鼓索神経刺激による唾液分泌が唾液腺からの

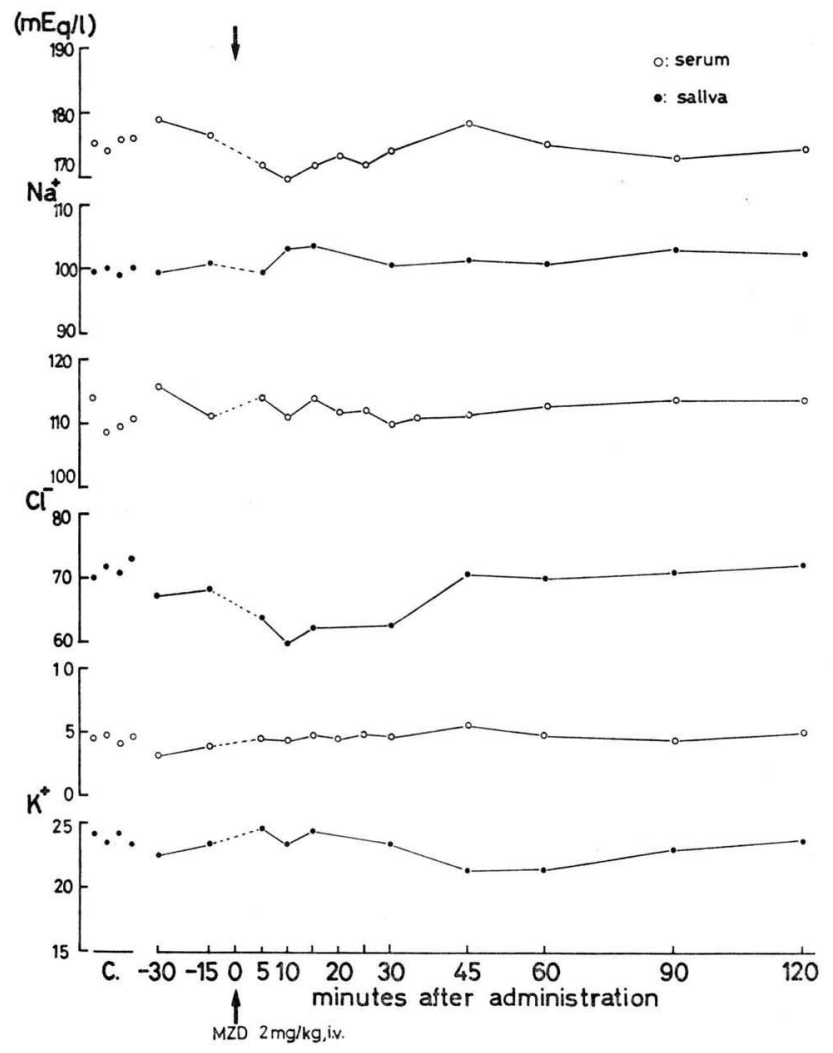

Fig. 5 Effects of mazindol (MZD) on $\mathrm{Na}^{+}, \mathrm{Cl}^{-}$and $\mathrm{K}^{+}$ion concentrations in saliva and serum. Open circles: serum. Closed circles: saliva. Abscissa: C-pretest measurements in each of four subjects. Time in min before and after injection of subject number 2. Ordinate: concentrations of ions in $\mathrm{mEq} \mathrm{1-1}$. Upper two traces: $\mathrm{Na}^{+}$. Middle two traces: $\mathrm{Cl}^{-}$. Bottom two traces: $\mathrm{K}^{+}$. 
$\mathrm{K}^{+}$脱出が惹起されなく，また血清中の $\mathrm{K}^{+}$も変化しな いことは，腺の $\mathrm{K}^{+}$の取り込又機構に mazindol が影 響を及洼さないことを意味している.

\section{2. mazindol の胃酸分泌に対する影響}

mazindol 投与による末梢性と中枢性の両方の胃酸分 泌に対する作用を，ラットを使用して検討した.

図6は，典型的コリン作働性剂の carpronium に対 して, mazindol $100 \mu \mathrm{g} / \mathrm{rat}$ (この場合約 $300 \mu \mathrm{g} / \mathrm{kg}$ に 相当）投与では carpronium による胃酸分泌をわずか に変化させたが， mazindol $50 \mu \mathrm{g} / \mathrm{rat}$ 投与では，まっ たく carpronium の作用が変化しないことを示してい る.また，図には示していないが，atropine $10 \mu \mathrm{g}$ 程 度でほぼ完全に carpronium のこの酸分泌を停止せし めることなどから, mazindol は末梢性胃酸分泌の酸分 泌量にも，分泌の持続時間にも影響しないといえる。ま た，胃潅流液の流速を遅らせた際に認められる「自発性 胃酸分泌」は， mazindol 投与により，やや抑制される 傾向が認められたが，本研究の実験方法からは，詳細な 検討を行らことはできなかった.

一方, 中枢性胃酸分泌に対する mazindol の作用は,
図7と図 8 の上段にその成績の一部を示した。insulin の大量 $(80 \mathrm{U} / \mathrm{kg})$ 投与による低血糖によって起こる胃 酸分泌に対する影響は，図７に示した，図の左側に，典 型的な insulin による胃酸分泌を示してあるが，この 例の酸分泌までの潜時，分泌の持続時間，そしてその酸 分泌量を右側に破線で描いて, mazindol 投与後の実験 と比較してある.この図でも明らかに示されているが, mazindol $100 \mu \mathrm{g}$ の静注後10分, 再び insulin を前回 と同量の $80 \mathrm{U} / \mathrm{kg}$ 皮下投与しても，通常の平均的潜時 である約60分を遥かに30分以上も超えて, 約 90 分の潜時 の後, 総酸分泌量も極めて少ない酸分泌を認めたにすぎ なく，かつ，その持続時間も有意に短縮された. 図に示 した例を含め16例中14例に於てこの抑制作用を認めた。 また，図8の上段には 2-DG に対する成績を示してあ る. insulin の場合と同様の mazindol の作用である。 即ち, mazindol $50 \mu \mathrm{g}$ の静注で, $2-\mathrm{DG} 150 \mathrm{mg} / \mathrm{kg}$ (i.v.) による胃酸分泌の潜時の著明な延長, 酸分泌量お よび分泌の持続時間を極めて有意に減少させた．しかし ながら, mazindol $50 \mu \mathrm{g}$ 投与後約 2 時間を経過して からの 2-DG 単独投与の場合でも，かなり mazindol

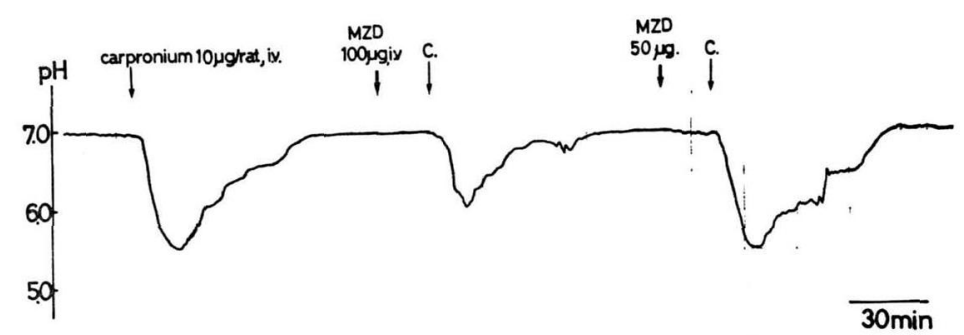

Fig. 6 Effects of peripheral mazindol on carpronium induced gastric acid secretion. In this example, mazindol (MZD) at $100 \mu \mathrm{g}$, i.v., per rat slightly suppressed gastric secretion induced by carpronium (G), but MZD at $50 \mu \mathrm{g}$ had no effect. In most trials, MZD at $100 \mu \mathrm{g}$ had no effect on $\mathrm{C}$ induced gastric acid secretion (not shown). Abscissa: time, $30 \mathrm{~min}$ calibration. Ordinate: $\mathrm{pH}$. Arrows indicate times of injection of the indicated substance.

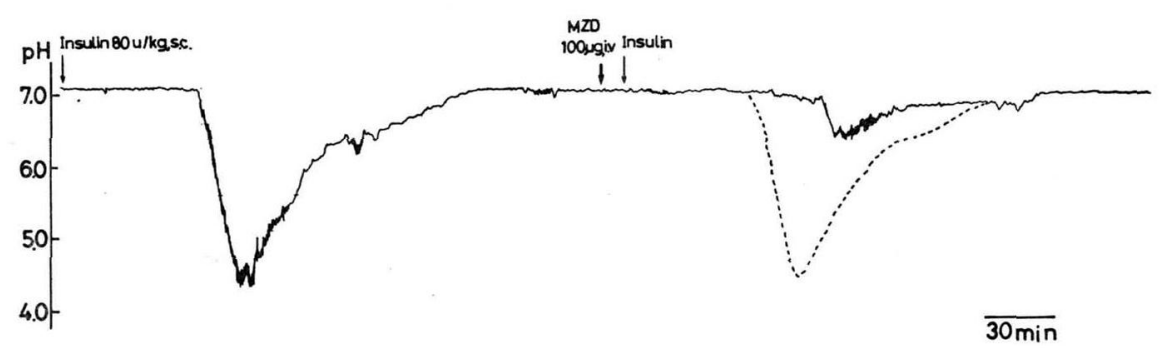

Fig. 7 Effects of peripheral mazindol on insulin induced gastric acid secretion. Mazindol (MZD) at $100 \mu \mathrm{g}$, i.v., per rat almost completely suppressed gastric secretion induced by insulin $(80 \mathrm{U} / \mathrm{kg}$, s.c.) . Abscissa: time, $30 \mathrm{~min}$ calibration. Ordinate: $\mathrm{pH}$. Arrows indicate times of injection of indicated substances. 

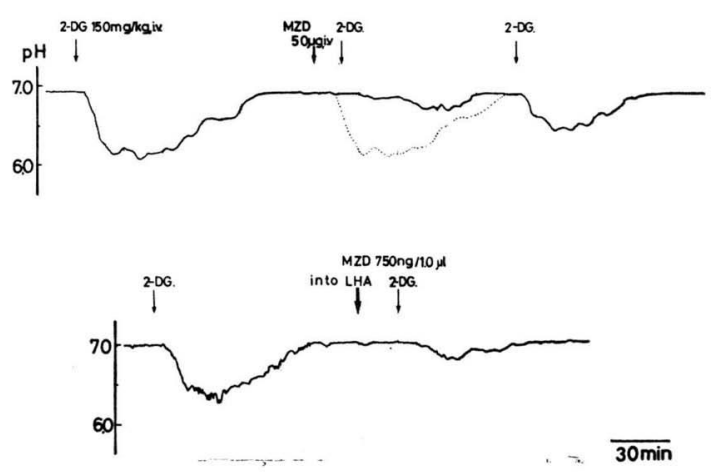

Fig. 8 Comparison of effects of mazindol on 2-DG induced gastric acid secretion when mazindol was applied peripherally or centrally. Both peripheral (50 $\mu \mathrm{g}$, i.v. per rat) and central $(750 \mathrm{ng} / 1.0 \mu \mathrm{l} / \mathrm{rat}$ into LHA) applications of mazindol (MZD) had the same effect, almost complete suppression, on 2-DG induced gastric acid secretion. Abscissa: time, $30 \mathrm{~min}$ calibration. Ordinates: $\mathrm{pH}$. Arrows indicate times of injection of indicated substances.

の影響が完全にないとは認め難い成績であった。この mazindol の作用は，100 $\mu \mathrm{g}$ 投与の場合には完全抑制 を 8 例中 7 例について認め, その後の 2-DG の回復も 極めて悪かった.

この insulin または 2-DG の胃酸分泌については, その用量と反応との関係は, 特に詳細に先に報告》して いる. insulin, 2-DG ともに6 例ずつのラットを用い, 3 用量を順不同で繰り返し，一定時間間隔で，それぞれ 18回ずつ投与し, その得られた成績, その平均值之最 小自乗法で得られた直線回㷌は推計学的に, insulin, 2-DG の両者とも極めて有意 $(\mathrm{P}<0.01)$ である. この ことから, この mazindol 投与により, insulin の場合 には， $87.5 \%$ (14/16) とその酸分泌を抑制した. 2-DG の場合, mazindol $100 \mu \mathrm{g}$, i.v. で完全抑制を示したも のが $87.5 \%$ (7/8), 図 8 上段程度の $50 \mu \mathrm{g}$ の場合は $90 \%$ (9/10) と抑制した.

その $\mathrm{pH}$ の変化としての酸分泌量に対しては, プラニ メーターで面積比として, mazindol $100 \mathrm{mg} / \mathrm{kg}$, i.v. 投与前後の比較を求めた結果は, insulin の場合, mazindol 投与前の $80 \mathrm{U} / \mathrm{kg}$, s.c. の insulin の酸分 泌が 54.8土10.1 飞対して, 投与後の同量の insulin $80 \mathrm{U} / \mathrm{kg}$ の際の值は, $11.5 \pm 2.8(\mathrm{n}=16)$ と極めて有意 $(\mathrm{P}<0.01)$ Kazindol は insulin に依る酸分泌を抑 制した.

一方, 2-DG $150 \mathrm{mg} / \mathrm{kg}$, i.v. の場合, insulin の場
合と同じく mazindol $100 \mu \mathrm{g}$ 投与の場合は完全抑制さ れたものが87. $5 \%$ であったが， $50 \mu \mathrm{g}$ の投与の場合は， mazindol 投与前後では, それぞれ 21.4 $\pm 3.6,9.1 \pm 2.3$ $(n=10)$ と明らかに（P<0.01), mazindol 飞よって 2-DG 飞依り惹起される胃酸分泌は抑制された.

これら insulinや2-DG に上る胃酸分泌は，両側迷走 神経切断で当然のことながら完全に消失することから， mazindol の insulin と 2-DG の胃酸分泌作用に対す る影響から，その作用は中枢性の胃酸分泌対して抑制 するものと示唆された．そこで，中枢性胃酸分泌を直接 統御する細胞の存在することが知られている視床下部の 外側野 (LHA) に, 直接 mazindol の微量を投与した 場合の 2-DG の胃酸分泌対する作用を検討してみた. 四8の下段は，上段と同様に，2-DG $150 \mathrm{mg} / \mathrm{kg}$ によ り明膫な胃酸分泌が認められ, 完全に投与前のレベルに 回復の後, mazindol $750 \mathrm{ng}$ を $1 \mu 1 \mathrm{LHA}$ 内の胃酸分 泌に関与するニューロン群の分布密度が最も高い部位に 投与してから約 20 分後再び 2-DG $150 \mathrm{mg} / \mathrm{kg}$ を静注し た例である.10例中10例の mazindol 微量 LHA 内投 与により, 胃酸分泌は明らかに抑制された。なお，因に は示していないが, mazindol $1 \mu \mathrm{g} / 1 \mu \mathrm{l}$ では 2-DGの 胃酸分泌作用の完全抑制が認められた，因みに insulin の場合は, 投与から酸分泌の発現までの時間が通常60分

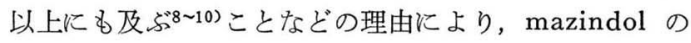
LHA 内投与による insulin の胃酸分泌汶対する検討 は行わなかった。 この mazindol の作用は, 静注の場 合も LHA 内微量投与の場合の両者ともに, 中枢性胃 酸分泌抑制作用には用量と反応の間に明らかな相関があ った.

以上のごとく, mazindol は視床下部に直接作用し, そこが統御する胃酸分泌㳔して抑制効果を示すことが 明らかになったので, 次に, それら視床下部のニューロ ン自身に対する作用を検討してみることにした．それ は，胃酸分泌を促進する部位である LHA 内ニューロン と，LHA に対して抑制作用をもって相反する機能を示 す腹内側核 (Nucl. ventromedialis，VMH）の両者 内に存在する特異的なニューロンに対する作用の検討で あった.

図9は，LHA ニューロンに対する mazindol の作 用の一例を示したもので，上段は 2-DG の電気浸透的 投与により応答するブドウ糖感受性ニューロン（glucose-sensitive neuron) のらち，その興奮に胃酸分泌 を伴わないもの (non-gastric type) である. 即ち, 2-DG $30 \mathrm{nA} \mathrm{15}$ 秒間投与飞より明らかに放電頻度の 


\section{LHA:}

\section{non gastric type:}

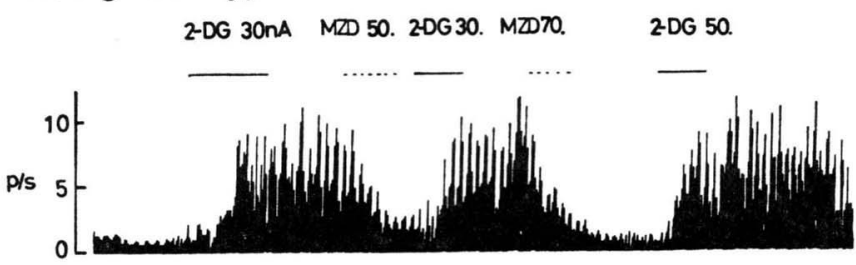

$10 \mathrm{~s}$

\section{gastric type:}

2-DG50 MZD 40

$M Z D 20$.

2 DG50. 2DG 30.
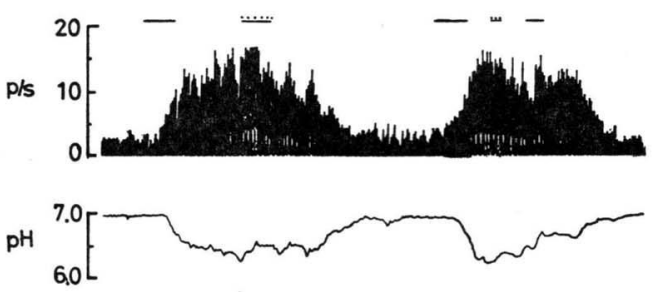

$3 \mathrm{~min}$

Fig. 9 Modulation of 2-DG effects in LHA by mazindol. In upper example, mazindol (MZD) suppressed the effect of 2-DG on the non gastric type glucose sensitive neuron, but had no effect on gastric acid secretion (not shown). It had no effect on activity or gastric acid secretion when applied alone on glucose sensitive neurons (not shown). In the lower example, MZD suppressed both neuronal activity and concomitant gastric acid secretion due to electroosmotic 2-DG. Abscissa: time, 3 min calibration. Ordinates: pulses per sec. upward: $\mathrm{pH}$, downward (lower example only). Overbars and markings indicate time of application, material, and relative doses, $\mathrm{nA}$.

増加が認められる. その後興舊がピークに達した頃, mazindol $50 \mathrm{nA}$ の投与により, 著明な発火頻度の減 少があった. つまり，2-DG の投与により発火した glucose-sensitive neuron の興奮は mazindol によ って抑制されたといらことである. その後の mazindol 70 nA では, より強い抑制効果を示した. この細胞が偶 発的にその発火頻度が低下したことでないこと，あるい は， mazindol 投与時の電流によるアーチファクトでな いことは，引き続き投与した 2-DG により再びこの細 胞の放電頻度が増すこと, 即ち発火レベルが上昇するこ とから,これらのことは否定できた. 図9の下段は, 上段と同様に 2-DG の投与により放電頻度が上昇した glucose-sensitive neuron であるが, 同時にその興奮 に伴って胃酸分泌を認めた gastric type のニューロン に対する mazindol の作用を検討したものの1例を示 している。即ら，2-DG $50 \mathrm{nA}$ の投与により放電頻度 が上昇すると, それとほとんど同時に胃潅流液の $\mathrm{pH}$ の 低下（胃酸分泌）が認められ，その両者は mazindol で
顕著に抑制された例を示している.このニューロンの発 火の変化が，明らかに $\mathrm{pH}$ の変化と一致していることが 注目された。 しかしながら, mazindol は LHA 内の glucose-sensitive neuron でない一般のニューロンに 対してはほとんど作用を示さなく（95.0\%), gastric お よび non-gastric type の glucose-sensitive neuron に対する作用は特異的である. 特に gastric type の二 ニーロンは全例が「抑制」を示した. LHA ニューロン に対する mazindol の作用を12例のラット，156ニニッ トのニューロンについての結果（表 2) は, 156のうち $123(78.8 \%)$ が non-glucose-sensitive neuron であっ た。 そのうち mazindol によって放電頻度が増加した ものは 4 (3.3\%), 減少したものは1（0.8\%）で，変化 しなかったニューロンは118（95.9\%）であった. 156個 のニューロンのらち33(21.2\%) が, 2-DG や insulin によって発火した glucose-sensitive neuron であっ た，光のうち，6（18.2\%，LHA 全検索ニューロン

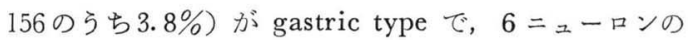


Table 2 Effects of mazindol on the LHA and VMH neuronal activity

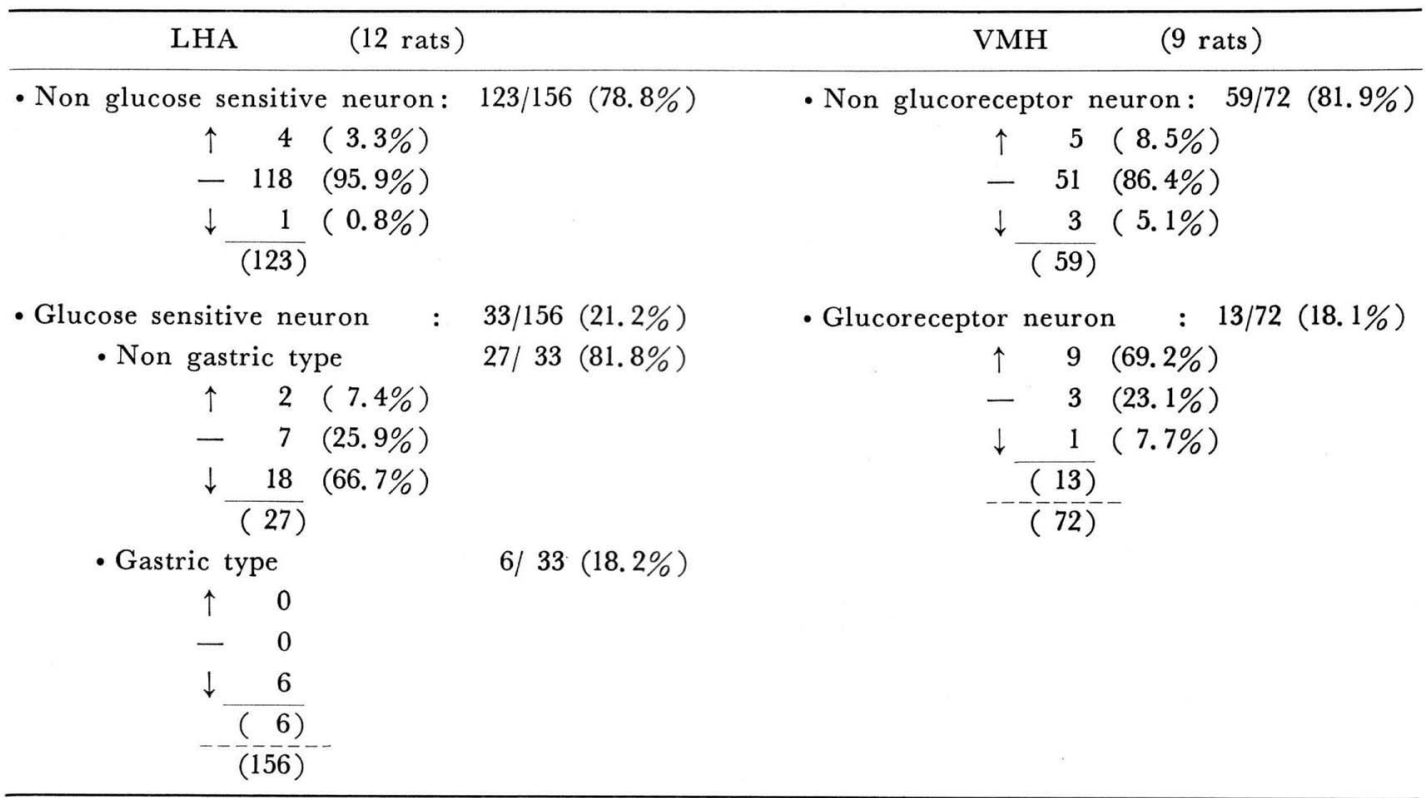

VMH:
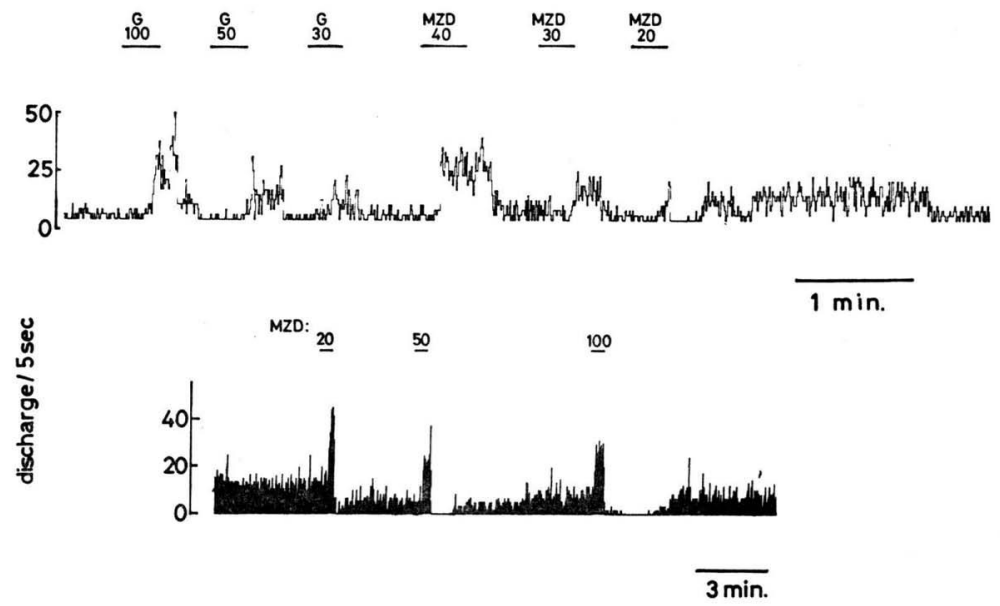

Fig. 10 Effects of mazindol when applied electroosmotically on neurons in VMH. Upper trace: when applied on glucoreceptor neurons, mazindol (MZD) induced a dose responsive increase in activity. Lower trace: glucose had no effect on this neuron (not shown), but mazindol caused transient excitation (positively dose related), followed by suppression (duration, inversely dose related). Abscissas: time, calibration as indicated (note different time scales). Ordinates: discharges per $5 \mathrm{sec}$ as indicated. Overbars and markings indicate times of application, material, and relative doses, $\mathrm{nA}$.

全例がmazindol により，そのニューロン活動が抑制さ れた. glucose-sensitive neuron のらち，27(81.8\%) は non-gastric type であったが, mazindol により 7
(25.9\%) が変化なく, $2(7.4 \%)$ が発火頻度を増加, $18(66.7 \%)$ が減少を示し, mazindol は non-gastric type の glucose-sensitive neuron にも強い抑制効果 
を示した.

一方, LHA に対して抑制的に機能する VMH 内の ニューロンの中には, glucose の投与により, その放電 頻度の上昇するニューロン(ブドウ糖受容性ニューロン, glucoreceptor neuron) が存在する. この glucoreceptor neuron と glucoreceptor neuron でないニュー ロンに対する mazindol の作用を検討し，その一部を 図10に示した。図上段は, glucose 100,50,30 nA で それぞれ用量と反応が明らかに相関し, 放電頻度を增し ているニューロンの例, 即ち glucoreceptor neuron である. その後, mazindol 40, 30, $20 \mathrm{nA}$ と, glucose 々同様に, 用量一反応的に放電頻度が上昇している例を 示している. 図下段には，non-glucoreceptor neuron を示してあるが， mazindol 投与により，それぞれの放 電頻度を増加させた例を示している。この mazindol の $\mathrm{VMH}$ ニューロンに対する促進作用で注目されたの は, mazindol の投与量が 20, 50, $100 \mathrm{nA}$ と增加するに したがって, 初期相のインパルス增加率が減少すること と, その投与直後の促進のすぐあとに続いて認められる 顕著な抑制相があること, そして mazindol が, 20, $50,100 \mathrm{nA}$ と増すにしたがい，その抑制相の持続時間 を延長させるというニニークなニューロン活動を示した ことであった. 9 例のラット, 合計72ユニットの $\mathrm{VMH}$ ニューロンのうち 59 (81.9\%) が non-glucoreceptor neuron といら結果であった. mazindol は, 図10下段 に示した特長あるニューロンを含め， $5(8.5 \%)$ の放電 頻度を増加させ， $3(5.1 \%)$ 減少, 51 (86.4\%) は変化 しなかった. 一方, 72 ニューロンのらち13 (18.1\%) が glucoreceptor neuron であった. そのらち mazindol は9 $9(69.2 \%)$ を增加, $3(23.1 \%)$ は変化なし, 1 (7.7\%)の放電頻度を減少させた.

これらの成績から, mazindol は直接 LHA ニュー ロン活動を抑制させ， VMH ニューロンにはその興奮 性を充進させたとい光, 先の中枢性胃酸分泌に対する mazindol の作用は，LHA に対する作用之VMH V 対する作用の統合された結果の「抑制効果」であると示 唆された.

以上の, LHA と VMH ニューロンに対する mazindol の作用を表 2 に総括した.

\section{考察}

細胞はその機能を維持し, 自己を存続させるために, 常に物質をとり込みから放出している. したがって，す べての細胞にとって, 分泌と吸収の機能は基本的なもの
とい党る16). 今回の研究は, その「分泌腺」について行 った. 分泌腺は単に自己存在のためのみでなく, 生体の 他の部分にとっても, 必要な物質を輸送するように分化 発達した組織である. 分泌腺のうち, 特に唾液腺である 顎下腺と胃腺に注目した.

従来の肥満治療剤の代表的なものの一つに, 我が国で は用いられることはないが欧米に於いては amphetamine が挙げられる. しかし, 肥満そのものの関心が 高まるに従い，副作用の点からも amphetamine に 代わる薬剤の登場が待たれていた，今回実験に用いた mazindol は, amphetamine とは化学構造的に異なる 三環化合物で, 既に欧米では, 肥満の治療剤として市販 されているものである.

唾液腺におけるイオン輸送と連結した水の受動輸送 も, いままでは水能動輸送と考兵られていたものが, 受 動輸送が生体膜水輸送の本態であると考えられるに至っ ている ${ }^{17)}$. その意味からも, 本研究に用いた顎下腺によ る唾液の輸送速度と駆動力についての観察は興味深かっ た.

分泌腺の水輸送速度すなわち分泌速度は, その腺の種 類, 状態, 刺激強度により変わる(18)が, 本研究では腺重 量当りにしての水輸送速度で表わした. イ邓の場合, 鼓 索神経刺激で最高 $600 \mu 1 / \mathrm{min} / \mathrm{g}$ の分泌速度が得られ る19)といらが，本実験では，方法がやや異なるにせよ， ほぼ同程度の分泌速度を示するのが, mazindol によっ て，ほとんど影響を与えなかった，いずれにせよ，腺の 水輸送速度は非常に高く, イ又㴿下腺の場合，1分間に 移動する水の量が腺細胞内全水分量を上回るということ になる。したがって, 本研究では, 分泌された唾液が導 管を通って排出口に至り，そこの唾液を測定したわけ で，導管内でのイオンの再吸収があるが水の透過性は低 く再吸収はほとんどないので20), mazindol 投与によ り，これに差がないことから，分泌された唾液には浪と んど変化を与学なかったということがいえよう．刺激に よって分泌された唾液量については, 化学刺激でも電気 刺激の場合でも，有意に減少した。これは，本実験の mazindol の作用について注目される点であろう。 た，分泌の駆動力すなわち分泌圧に打いても， mazindol 投与により生食投与の対照よりも低い值を示したが，先 の分泌量に対する作用との相関で興味深いものがある. 分泌压の発生原因が単に腺腔周囲飞ある筋上皮細胞の収 縮のみによるものではなく, 高静水圧に拡がった水の輸 送によるものである ${ }^{19} こ と は 今$ 回の実験でも明らかにさ れ，Ludwig 21) の提唱する水輸送機構が単純な濾過では 
ないことを裏付けた、いずれにせよ，水輸送は流速 $\times$ 駆 動力で表現されるわけであるから， mazindol の軼液分 泌「抑制」の意義は分泌速度には変化はなく, 駆動力が 低いため分泌量が少ない結果となったわけであろう。乙 たがって， mazindol が示した自発性分泌汶対する抑制 も当然の結果かもしれないが，本実験がすべて「刺激」 による分泌に対する作用の検討であったので，それにつ いては, さらに詳細な研究が待たれる.

イオンについては, 唾液腺の輸送されるイオンの大部 分が $\mathrm{Na}^{+}$と $\mathrm{Cl}^{-}$と $\mathrm{K}^{+}$である.これらが血液側から 腺腔側へと輸送されている. 分泌汶するイオンの依存 性は $\mathrm{Na}^{+}$が最も高く22 23), また $\mathrm{Cl}^{-}$濃度の減少は分泌 には影響させないといら ${ }^{23)}$. したがって，分泌の原因で あるイオン輸送を考劣るとさ， $\mathrm{Na}^{+}$か $\mathrm{Cl}^{-}$かのいずれ かは細胞を通過するものと思われるが，イオンとしては $\mathrm{Cl}^{-}$よりも $\mathrm{Na}^{+}$の涪らが強いという ${ }^{199} . \mathrm{Na}^{+}$が血液側 より基底膜側から細胞内に入り, 腺腔側膜より放出され るのであろう. 細胞内の $\mathrm{Cl}^{-}$の濃度は高く, 細胞内電 位によった受動的分布をしているという24)。これは，細 胞膜の $\mathrm{Cl}^{-}$透過性の高いことを示している. Burgen ${ }^{25)}$ は, 分泌刺激气のものが分泌腺からの $\mathrm{K}^{+}$脱出を惹き 起こすことを発見した．この $\mathrm{K}^{+}$脱出は腺腔側のみなら ず，血液側にも起きる. 水輸送に重要な意味をもつイオ ソの変化であるが mazindol は先の分泌圧や速度に対 する変化にもかかわらず, イオン輸送には影響を及ぼさ ないことから, 水輸送の駆動力乞のものは変化させない とい光よう。言い換光ると, mazindol によって認めら れた唾液分泌量や分泌圧の減少は, 分泌腺の分泌機能の 基本には変化させないとい方よう，生体での水の輸送方 法には前述のように能動的なものはなく，静水圧による か, 浸透圧によるものでなければならない，腺組織の静 水圧差は有効な駆動力とはなり難く, イオン輸送による 晶質浸透圧差のみが水輸送の駆動力となる ${ }^{19)}$. したがっ て, 本研究により得られた唾液分泌抑制作用は極めて興 味ある多くの問題を残したことになり，今後さらに種々 の（例觉ば動物の当, 唾液の採取方法, 刺激の条件な ど）実験条件を変化させて, 詳細な検討が必要之思われ る. 今後の研究が待たれるところである.

Zahorska-Makkiewicz (1980) によれば, mazindol 投与中の肥満患者が, 投与後約 3 カ月頃より「口渴」を 訴えるとい5 ${ }^{26}$. 唾液分泌を 28 人の肥満者と 10 人の非肥 満者で測定したところ，自発的唾液分泌は両者とも大差 はないにもかかわらず, mazindol はベイサルと刺激 （被験者は食物のことを考觉る、レモンを見せ，嗅がせ
る）の両方の分泌を有意に減少させたという．このこと から， mazindol 投与による副作用の「口渴」は，むし ろ本剤の主作用つまり「食欲」を調節する視床下部の摂 食中枢への直接作用の結果であることを示唆するものと 考光る. 食欲中枢の活動は「唾液分泌」として表出され よう，その分泌を抑制するということは，本剤の主作用 の目的を十分に適光ると思われる.

このことは, 胃酸分泌に於ける実験で意味づけられた と思われる. 視床下部外側野（LHA）が摂食中枢で, 腹内側核 $(\mathrm{VMH})$ が満腹中枢であることはよく知られ ている27)，その LHA 内には 2-DG p insulin の投 与によって興奮しフブド糖によって抑制される細胞 (glucose sensitive neuron) が存在しているが, この ニューロンは摄食に関与するばかりでなく, 同時に胃酸 分泌を直接統御するるのである ${ }^{2,10,27)}$. 今回の, insulin や 2-DG によって生ずる胃酸分泌は，LHA 内の特定 部位の破壞や迷走神経切断により低血糖を呈していても (2-DG の場合は functional cytoglucopenia) 酸分泌 が認めら机なくなる8「「中枢性」胃酸分泌である。これ らの酸分泌は, 先に述べた glucose sensitive neuron （特に gastric type）が，insulin による低血糖により cytoglucopemia（細胞内プドウ糖欠乏）に宿って，そ の結果の「興奮」が胃酸分泌を誘起させるわけである. 本研究に用いた mazindol は LHA 内のこの細胞に恐 らくは直接働き，その結果胃酸分泌が抑制されたものと 考觉る. これは, mazindol を直接 LHA 内の特定部 位に $1 \mu \mathrm{g}$ 以下といら微量を投与しても2-DG の胃酸 分泌を停止させ（図8），全身的投与をしても（図7,

8) insulin や 2-DG による胃酸分泌を停止させたこ とが示していた. しかも, 胃底腺の旁細胞に直接奏効す る末梢性胃酸分泌には，その抑制効果を示さなかったわ けである. さらに gastric type の glucose sensitive neuron の放電頻度を明らかに抑制し，その細胞の興奮 に伴っていた胃酸分泌も同時に抑制した. このことは, mazindol が直接 LHA, 即ち摄食中枢の特異的細胞に 直接関与するものであるとい方よう。一方 VMH（満腹 中枢）内のニューロンに対しても極めて興味ある注目さ れる成績であった（図10）．種々の作用機序が考光られ るが，VMH は他の大脳皮質や辺縁系などの作用之本 質的には異なり，直接 LHA に対する抑制作用が主な 機能であるとい方よう。 その VMH 内のニューロン, この場合は glucose の増加を感知する細胞 (glucoreceptor neuron) に対して, 明らかにニューロン活動 を促進させた．この mazindol の胃酸分泌抑制作用は, 
LHA に対する直接作用と同時に VMH にも作用し, その LHA に対する VMH の抑制作用を増強させる と思われる. しかも, 「満腹」に直接関与するとは思 われないニューロンに対して，極めて特長める影響を VMH に示した. それは, mazindol により, 放電頻 度が用量とは反比例して増加し, その直後からは用量一 反応的に著明な抑制を示す二相性作用を示した（図10下 段)ことである. 特に二次的に出現した抑制効果につい ては, 脳内ノルェピネフリンの代謝を mazindol が変 えるといら報告もある28ことから, 恐らくそれによるも のかもしれなく, 興味ある点であり, その解明は今後の 課題にしたい. いずれにせよ, VMH に対する mazindol の作用は「促進」で岕り, LHA 内の非特異的二ュ ーロンに対する抑制効果がほとんどない(1/123，0.8\%) ことに比較すれば, $\mathrm{VMH}$ 内の非特異的ニューロンに 対する促進効果 $(3 / 59,5.1 \%)$ は何らかの意味が含まれ ていると思われるが，現在のところ不明である.

本研究に用いた mazindol の肥満治療についての報 告はかなりあるが29 34)，いずれも安全で効果的な薬剂で あるとし, その臨床上の効果が期待されている. しかし ながら，その作用機序については，不明な点も多々あ る. 本研究がその解明に少なからず寄与するものと思わ れる. 今回の実験により, 垂液分泌の減少, 胃酸分泌の 減少, またこれらの現象が視床下部の摂食中枢や満腹中 枢に対する直接作用の結果, 二次的に若起されたといら ことである. また，個々についての詳細な検討を行なう 必要がある. LHA と VMH の視床下部相互間の統合 機序に関してもさらに研究が行われることになるらし, 他の内在性, 外因性の摂食機構に対する影響と, それら と肥満との関連性も残された問題であった.

謝辞：イオン定量について, 東海大学医学部共同利用研 究室生化学と東海大学医学部附属病院中央臨床検査室の 協力を得た. mazindol はサンド薬品株式会社より提供 された，茲に感謝の意を表わす。

\section{文献}

1) 繁田幸男, 三子亘由 : 総合臨床 20, 277 (1971)

2) Shiraishi, T., Tsutsui, K., Sakata, T. and Simpson, A.D.: The Neural Basis of Feeding and Reward, Edited by Hoebel, B.C. and Novin, D., p. 373 390, Hear Institute for Electrophysiological Research, Brunswick (1982)

3) Shiraishi, T.: Brain Res. Bull. 5, 245 (1980)

4) Evans, H.E. and Christensen, G.C.: Miller's Anatomy of the Dog, p. 926, W.B. Saunders Co., Philadelphia (1979)
5) 日本生理学会編：生理学実習書, p. 139, 南江堂 (1977)

6) Cotlove, E.: Clin. Chem. 7, 285 (1961)

7) Ghosh, M.N. and Schild, H.O.: Br. J. Pharmacol. 13, 54 (1958)

8) 白石武昌：日本生理誌 32, 203 (1970)

9) 井上敦郎, 白石武昌, 望月 徹, 矢内原昇 : 日薬理 誌 77, 61 (1981)

10) Shiraishi, T., Miyashita, T. and Takahashi, H.: Proc. IUPS XIII, 693 (1977)

11) Oomura, Y., Ooyama, H., Sugimori, M., Yoneda, K. and Simpson, A.D.: Physiol. Behav. 16, 799 (1976)

12) Skinner, J.A.: Neuroscience, Laboratory Manual, Saunders, Philadelphia (1971)

13) Albe-Fessard, D., Stutinsky, F. and Liboudan, S.: Atlas Stereotaxique du Diencephale du Rat Blanc, Editions du Centre National de la Rescherche Scientifique, Paris (1966)

14) König, J.F.R. and Klippel, R.A.: The Rat Brain, Stereotaxic Atlas of the Forebrain and Lower Parts of the Brain Stem, William \& Wilkins, Baltimore (1963)

15) Szentagothai, J., Flerko, B., Mess, B. and Halaz, B.: Hypothalamic Control of the Anterior Pituitary, An Experimental Morphological Study, Akademiai Kiado, Budapest (1962, 1972)

16) 今井雄介：日本生理誌 27, 304 (1965)

17) House, C.R.: Water Transport in Cells and Tissue, Arnold, London (1974)

18) Imai, Y., Nishikawa, H., Yoshizaki, K. and Watari, H.: Japan. J. Physiol. 23, 635 (1973)

19) 今井雄介：生体の科学 27, 123 (1976)

20) Kikkawa, T.: Japan. J. Ophthal. 14, 247 (1970)

21) Ludwig, C.: Z. Rat. Med. NF, 1, 255 (1851)

22) Petersen, O.H.: Experientia 26, 1103 (1970)

23) Petersen, O.H.: Acta Physiol. Scand. 381, 1 (1972)

24) Schneyer, J.H. and Schneyer, C.A.: Am. J. Physiol. 203, 567 (1962)

25) Burgen, A.S.V.: J. Physiol. 132, 20 (1956)

26) Zahorska-Markiewicz, B.: Gurr. Ther. Res. 27, 868 (1980)

27) Oomura, Y.: Handbook of the Hypothalamus Vol. 2, Physiology of the Hypothalamus, Edited by Morgane, P.J. and Panksepp, J., p. 557 620, Marcel Dekker, New York, Basel (1980)

28) Engstrom, R.G., Kelly, L.A. and Gogerty, J.H.: Arch. Int. Pharmacodyn. Ther. 24, 308 (1975)

29) Allen, C.S.: Curr. Ther. Res. 22, 678 (1977)

30) DeFelice, E.A., Bronstein, S. and Gohen, A.: Curr. Ther. Res. 11, 256 (1969) 
31) Evans, E.R. and Wallance, M.G.: Curr. Ther. Res. Opinion 3, 132 (1976)

32) Grapin, B. and Gohen, A.: Int. Med. Dig. 9, 15 (1974)
33) Eicinaki, A. and Staakak, L.: Pol. Arch. Med. Wewn. 55, 581 (1976)

34) Zahorska-Markiewicz, B.: Pol. Tyg. Lek. 31, 1085 (1976)

\begin{abstract}
Takemasa SHIRAISHI (Department of Physiology, Tokai University School of Medicine, Bohseidai, Isehara, Kanagawa 259-11, Japan). Mazindol effects on the salivary and gastric acid secretory mechanisms. Folia pharmacol. japon. 83, 159 172 (1984)

The effects of mazindol on the salivary secretion of dogs was investigated. Mazindol (2 mg/kg, i.v.) decreased the volume and pressure of salivary secretion induced by either chemical (carpronium) stimulation or electrical nerve stimulation. It also reduced spontaneous salivary secretion. Secretion velocity in the mazindol treated group was significantly less than in the physiological saline administered control group at 4 to 6 min after injection. Saline and mazindol produced no significance differences in $\mathrm{Na}^{+}, \mathrm{Cl}^{-}$or $\mathrm{K}^{+}$concentrations in the saliva or serum. Thus mazindol inhibition of salivary secretion was not caused by ion transport. The existence of some other inhibitory mechanism is suggested. The effects of mazindol on the peripheral and central control of gastric acid secretion was also investigated in rats. Gastric acid secretion induced by direct application of cholinergic agents on oxyntic cells was not affected by mazindol. Gastric acid secretion induced by insulin and/or 2-DG, on the other hand, was markedly inhibited by intra-hypothalamic injection or systemic (i.v.) injections of mazindol. Electroosmotic mazindol mimicked the effects of glucose in the lateral (inhibition) and ventromedial (excitation) hypothalamus. The results suggest that the inhibitory effects of mazindol on salivary secretion may be through the hypothalamic feeding control centers. Mazindol also directly affected gastric acid secretory neurons in the lateral hypothalamus. It might thus be expected to be effective in the treatment of obesity.
\end{abstract}

